\title{
Qualitative and quantitative analysis of formaldehyde in samples of hair straighteners and suitability of the labels
}

\author{
Amanda Letícia Polli Silvestre ${ }^{1,2 *}$, Maira Fagá2, Maria Gabriela José de Almeida-Cincotto², \\ Bruna Galdorfini Chiari-Andréo², Thalita Pedroni Formariz ${ }^{2}$ \\ ${ }^{1}$ Departamento de Fármacos e Medicamentos, Faculdade de Ciências Farmacêuticas, Universidade Estadual Paulista Júlio de \\ Mesquita Filho - (UNESP), Araraquara, SP, Brasil \\ ${ }^{2}$ Departamento de Ciências Biológicas e da Saúde, Universidade de Araraquara (UNIARA), Araraquara, SP, Brasil \\ *Corresponding author: amanda.silvestre@unesp.br
}

\begin{abstract}
Formaldehyde is an active compound, irregularly used in hair products, that has the property of straighten and waterproofing the wires. However, it is highly toxic and can stimulate dermatological hypersensitivity and cancer. In this context it is of fundamental importance the inspection of these products that can be used in safe conditions for the consumer, without formaldehyde in concentrations higher than the allowed. Thus, the aim of this research was the qualitative and quantitative identification formaldehyde in samples of hair straighteners that was obtained by donation in the beauty salons of Araraquara-SP. In addition, the analysis of the packaging labels of the products tested were conducted, following the requirements of the national legislation - RDC 07/2015 which defines the mandatory labeling standards for cosmetic products. A qualitative analysis for formaldehyde identification is based on the formation of a purple colored complex. The quantitative analysis was performed by spectrophotometry. The qualitative and quantitative formaldehyde analysis methods were applied to 13 bottles of hair straighteners. When submitted to qualitative analysis, all samples showed formaldehyde presence. The quantitative analysis demonstrated that the samples identified as $B, C, D, E, G, H, I, J$ and $M$ presented formaldehyde concentration of 3.5 to $14.5 \%$, which is above of the limit recommended by the National Health Surveillance Agency (ANVISA), of $0.2 \%$. In the label analysis, in all samples were found irregularities.
\end{abstract}

Keywords: Formaldehyde. Hair Straightener. Qualitative Analysis. Quantitative Analysis. Spectrophotometry.

\section{How to cite}

Silvestre ALP, Fagá M, Almeida-Cincotto MGJ, Chiari-Andréo BG, Formariz TP. Qualitative and quantitative analysis of formaldehyde in samples of hair straighteners and suitability of the labels. Rev Ciênc Farm Básica Apl. 2020;41:e648. https://doi.org/10.4322/2179-443X.0648

\section{INTRODUCTION}

A few years ago, a new procedure for hair straightening was introduced in Brazilian beauty salons. This procedure consists of a technique that promotes long-lasting hair straightening, from one to four months, and has different names, such as progressive, definitive, intelligent brush, smoothing, relaxing and defrizing, among others. This technique has the main 
objective of changing the structure of the hair wires, making them smoother (Leite et al., 2018; Franquilino, 2013).

The products used in hair straightening are classified as cosmetics with a risk level equal to 2 according to Resolution No. 07 of February $10^{\text {th }}, 2015$ of the National Health Surveillance Agency (ANVISA). This classification is justified by having substances toxic or harmful to humans (Brasil, 2015).

Formaldehyde has been used since the 1990s in disinfectant, germicide, antiseptic and to embalm cadavers. In addition, it can be applied in glass and mirrors, explosives, in urea solutions and derivatives, for the production of pesticides. In cosmetic products, it could be added as a preservative, in very low concentrations, due to its antimicrobial action (Ucko, 1992; Martins et al., 2017; Instituto Nacional de Câncer, 2018).

The literature shows that formaldehyde is incorporated in hair straightening products due to its property of waterproofing the wire through the connection with the proteins and the hydrolyzed amino acids of the hair keratin, forming a film throughout the hair wire keeping it smooth and rigid for a certain period of time (Abraham et al., 2009a).

However, according to ANVISA, the incorporation of formaldehyde in hair straighteners is prohibited with the purpose of hair straightening. The health legislation allows its use only with the function of preservative in cosmetic products, present in a maximum concentration of $0.2 \%$ according to the Resolution No. 15 of 2013 (Brasil, 2013; Vitola et al., 2019).

Formaldehyde it is obtained through the oxidation of methanol and manufactured in a $37 \%$ $(w / v)$ aqueous solution (Alves \& Aciole, 2012). It is considered a simple aldehyde, having only one carbonyl carbon attached to two hydrogens - HCHO (Russel, 1994; Atkins \& Jones, 2011). It is a colorless, volatile liquid compound and exhibits a strong and irritating odor, in addition, it is soluble in water, toxic in high concentrations and can be flammable (Alves \& Aciole, 2012). Since it is a volatile compound, consumers and professionals who use this product category (hair straighteners) containing formaldehyde are highly affected, both by its irritating effect on the scalp, and more especially by the inhalation of this compound causing harmful effects to the health (Abraham et al., 2009a).

To substitute formaldehyde, other substances can be used. The hydroxides are traditionally employed, including sodium hydroxide, calcium hydroxide and guanidine hydroxide. They are used to react with keratin, promoting the cleavage of the disulfide bonds. Products containing thioglycolic acid and its derivatives, are also an alternative (Dias et al., 2020). Nevertheless, it is necessary to point that even exposing the professional and the consumer to risks and being prohibited by the legislation, the irregular use persists, and some reasons are the cost, since formaldehyde is considered cheaper than the others, the process of application is quicker and the hair presents an intense glare after application (Abraham et al., 2009b).

The irregular use of formaldehyde in hair straighteners is a concern for consumers and professionals, as the exposures to high concentrations can cause adverse reactions since when inhaled it is absorbed through the respiratory and gastrointestinal tracts. Because it is a volatile and toxic compound in high concentrations, it has the ability to cause allergies and irritation in the eyes, nose and throat. In addition, it could promote even more serious effects when in constant contact and high concentrations, such as leukemia, laryngitis, bronchitis, pulmonary edema, pneumonia, nasopharyngeal carcinoma and can even lead to death. Thus, formaldehyde is toxic if ingested, inhaled or if in contact with the skin, when used indiscriminately in concentrations not permitted by law, mainly for the hair straightening effect (Stewart et al., 2013; International Agency for Research on Cancer, 2006). Still, according to Draelos (1999) all chemical substances used for hair straightening are skin irritants; thus, when applying the product on the skin and scalp, greater care is necessary (Draelos, 1999).

In view of the need to curb the incorrect use of formaldehyde associated or added to hair products for the purpose of straightening, another resolution was issued, the RDC No. 36, of July 17,2009 , which prohibits the sale of formaldehyde ( $37 \%$ solution) in pharmacies, 
drugstores, supermarkets, warehouses and convenience stores, reducing the ease of purchasing this substance (Brasil, 2009).

Despite the risks and prohibitions, there are a variety of hair straighteners that are sold to beauty salons that contain formaldehyde in their composition, in concentrations higher than is allowed for preservative function. Some brands insert a lower concentration of formaldehyde in their labels so that the sale is within the allowed norms and hide its function, inserting it as a preservative, so that the use becomes permitted according to the legislation. In most cases, this irregularity is driven by the fact that formaldehyde offers a better result than other substances used for the straightening effect (G1, 2012; Diseró, 2019; Agência Nacional de Vigilância Sanitária, 2018).

However, even with regulations, the irregular use of formaldehyde in hair straighteners is still considerable, by guaranteeing the smooth and shiny effect quickly provided by this substance, in addition to being a low-cost product (Monakhova et al., 2013).

Thus, great attention should be directed to this subject, including the evaluation of the regularity and quality of the straighteners that are developed and launched in the cosmetic market. This attention should be primarily focused on the safety of users of this product, both individuals who want to straighten, as well as professionals, who maintain daily contact with these chemicals (De Souza et al., 2012).

There are several methods for determining formaldehyde in hair straighteners, which can be mentioned: High Efficiency Chromatography with Ultraviolet Detector (HPLC-UV), Liquid Chromatography with Visible Ultraviolet Detection (LC-UV/VIS), High Efficiency Chromatography with arrangement detector diodes (UPLC/DAD), among others (AIShehri \& AlMeshal, 2020; Miralles et al., 2018; Galli et al., 2015).

These methodologies usually employ organic solvents that generate toxic residues, thus, offering risks to the environment and to the operator. In addition, they depend on specific instrumentation, which is not often available (Silvestre et al., 2018). Based on these considerations, this study was conducted with a modified methodology described by Gasparini et al. (2008) making it even simpler, faster, environmentally friendly, using low volume of reagents and sample (Gasparini et al., 2008).

Therefore, considering this issue and the widespread use of hair straighteners, this study is justified, which aims to analyze qualitatively and quantitatively the presence of formaldehyde in hair straighteners samples collected in hair salons of Araraquara - SP, in addition to assessing the suitability of labels of these products.

\section{MATERIAL AND METHODS}

\section{Equipment and materials}

Analytical Balance (Shimadzu); Class A volumetric glassware and "Gilson" micropipettes from 10 to $100 \mu \mathrm{L}, 100$ to $1000 \mu \mathrm{L}$ and 500 to $5000 \mu \mathrm{L}$. Spectrophotometer (Biotek); Microwave (Consul) and TPP Microplate.

\section{Reagents and solutions}

All reagents used were of analytical grade. Chromotropic acid 99\% (LS Chemicals ${ }^{\circledR}$ ); $98 \%$ magnesium sulfate (LS Chemicals ${ }^{\circledR}$ ) and $37 \%$ formaldehyde $\left(\right.$ Chemco $\left.^{\circledR}\right)$ were used for quantitative analysis. The Schiff Reagent and sulfuric acid $\left(\right.$ Synth $\left.^{\circledR}\right)$ were used in the qualitative analysis.

Solutions and dilutions employed purified water $(18.2 \mathrm{M} \Omega \mathrm{cm})$ obtained from a Milli-Q system (Millipore). The stock solution of formaldehyde (Chemco) was prepared at 3,01 $\mathrm{mg} \mathrm{L}^{-1}$. Chromotropic acid was prepared at $1.25 \%(\mathrm{w} / \mathrm{w})$. Magnesium sulfate solution was prepared at 30\% (w/w). Schiff's reagent was prepared with $100 \mathrm{mg}$ of fuchsin (Synth) and dissolved in $75 \mathrm{ml}$ of distilled water at $80^{\circ} \mathrm{C}$. After cooling, $2.5 \mathrm{~g}$ of sodium sulfite (Synth) and $1.5 \mathrm{ml}$ of concentrated hydrochloric acid (LS Chemicals) were added. The volume was completed to 
$100 \mathrm{~mL}$, in a volumetric flask, with distilled water. Sulfuric acid was used in the concentration of $1 \mathrm{~mol} \mathrm{~L}^{-1}$. Working solutions of each sulfonamide were freshly prepared by appropriate dilution $\left(0,133 \mathrm{mg} \mathrm{L}^{-1}-0,538 \mathrm{mg} \mathrm{L}^{-1}\right)$ of the stock solution $\left(3,01 \mathrm{mg} \mathrm{L}^{-1}\right)$ with purified water in a volumetric flask.

\section{Samples preparation}

Thirteen samples (A-M) of hair straightener were kindly donated by beauty salons from Araraquara, SP - Brazil. For qualitative analysis, the samples were used directly from the original packaging, without previous dilution. On the other hand, for quantitative analysis, samples were prepared by dispersing $2 \mathrm{~g}$ of each sample, individually, in $100 \mathrm{~mL}$ of purified water.

\section{Qualitative analysis}

To perform the qualitative analysis of formaldehyde identification in the thirteen hair straightening samples, $2 \mathrm{~g}$ of each sample were weighed and two drops of $1 \mathrm{~mol} \mathrm{~L}^{-1}$ sulfuric acid and $2 \mathrm{~mL}$ of Schiff's reagent were added. The identification of the compound was visually proven by the instantaneous formation of a purple complex after shaking (Agência Nacional de Vigilância Sanitária, 2007). It was done only one time for each sample, considering the qualitative purpose of this assay.

\section{Quantitative analysis}

This analysis was performed using the methodology of Gasparini et al. (2008) with modifications. An analytical curve was prepared, correlating known concentrations of formaldehyde with the measured absorbance. The equation that describes this curve, determined by linear regression, was used to calculate the concentration of formaldehyde found in the samples. In the results, the concentration was expressed as percentage (\%) to allow verification of compliance according to the limit allowed by RDC No. 15/2013 (Brasil, 2013).

Spectrophotometric method it is based on the colorimetric reaction between formaldehyde and chromotropic acid in the presence of magnesium sulfate. When stirred and heated, they react, showing a reddish color, of intensity dependent on the concentration of formaldehyde (Gasparini et al., 2008).

In a microplate, a reaction was prepared between $150 \mu \mathrm{L}$ of the magnesium sulfate solution, $30 \mu \mathrm{L}$ of the chromotropic acid solution and $45 \mu \mathrm{L}$ of the dispersion of each hair straightening sample $(2 \mathrm{~g} / 100 \mathrm{~mL})$. After stirring, with the aid of a micropipette, the microplate was subjected to heating, using a microwave oven. This step was performed in a water bath, heating 20 seconds at high power, in intervals of 3 in 3 minutes, until completing half an hour of heating, not counting the intervals. Finally, the spectrophotometric reading was performed at a wavelength of $535 \mathrm{~nm}$.

\section{Labels analysis}

The analysis of the labels of primary and secondary packaging of hair straighteners was carried out by means of a critical visual investigation, observing the following criteria: product name; brand; register number; lot; expiration date; content; country of origin; manufacturer; CNPJ; composition; "Professional use" information; mode of use; warnings / restrictions on use; presence of the sayings: "Do not apply if the scalp is irritated or injured", "Keep out of the reach of children". These criteria are established by the National Legislation - RDC 07/2015 which defines the mandatory labeling standards for cosmetic products (Brasil, 2015). 


\section{RESULTS}

\section{Qualitative analysis}

The method for qualitative analysis of formaldehyde identification was applied to the thirteen samples, in triplicate. All the samples evaluated developed a pink / purple color in the presence of the reagent, considered, therefore, as a positive result for the presence of formaldehyde. There was variation in the intensity of the color produced, probably indicating variable concentrations of formaldehyde in the different samples.

Despite the aforementioned result, this qualitative analysis is not sufficient to indicate the irregularity of commercial formulations, since formaldehyde is allowed, in low concentrations, as an antimicrobial preservative. Thus, the quantitative analysis was conducted, aiming to obtain quantitative data about them.

\section{Quantitative analysis}

An analytical curve (absorbance versus concentration) of formaldehyde was constructed using $0.133 ; 0.200 ; 0.267 ; 0.334 ; 0.401 ; 0.468 ; 0.538 \mathrm{mg} \mathrm{L}^{-1}$ solutions. The absorbance was determined at $535 \mathrm{~nm}$, after submitting the sample to the reaction with chromotropic acid and magnesium sulfate, as described in the methodology. The results obtained in Figure 1 demonstrated a linear relationship between the analytical response (Abs) and the concentration of formaldehyde $\left(C_{F}\right)$, described by the equation of the line $A b s=2.5438 C_{F}+0.0496$, with a correlation coefficient value $\left(R^{2}\right)$ of 0.996 .

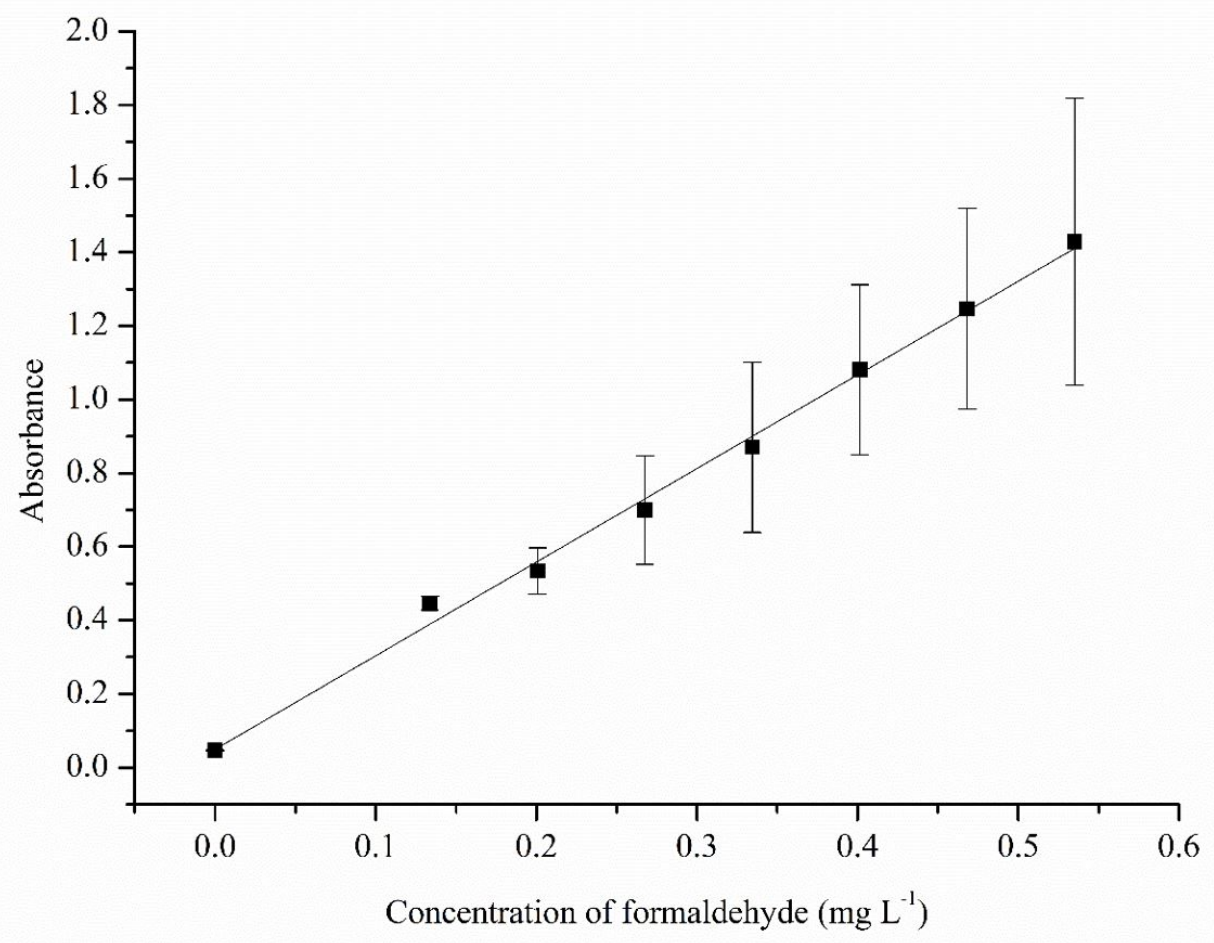

Figure 1. Analytical absorption curve as a function of formaldehyde concentration.

The results of the quantitative analysis of samples $A, B, C, D, E, G, H, I, J$ and $M$ indicated the presence of formaldehyde in formulations in concentrations from $0.1 \%$ to $14.5 \%$ as described in Table 1. The samples F, K and L were not subjected to this analysis due to the purple or bluish color of the products, a fact that interferes with the colorimetric quantification of formaldehyde. 
Table 1. Concentration of formaldehyde in hair straightening formulations.

\begin{tabular}{|c|c|c|}
\hline Sample & Concentration $\left(\mathrm{mg} \mathrm{L}^{-1}\right)$ & Concentration $(\%, w / v)^{a}$ \\
\hline A & 0.001 & $0.1 \pm 0.2$ \\
\hline $\mathrm{B}$ & 0.068 & $7.5 \pm 0.2$ \\
\hline $\mathrm{C}$ & 0.032 & $3.5 \pm 0.4$ \\
\hline $\mathrm{D}$ & 0.131 & $14.5 \pm 2.0$ \\
\hline$E$ & 0.032 & $3.5 \pm 0.1$ \\
\hline $\mathrm{F}$ & ${ }^{b} N D$ & ${ }^{b} N D$ \\
\hline G & 0.065 & $7.2 \pm 0.5$ \\
\hline $\mathrm{H}$ & 0.061 & $6.7 \pm 0.2$ \\
\hline 1 & 0.060 & $6.6 \pm 0.3$ \\
\hline J & 0.048 & $5.3 \pm 0.1$ \\
\hline $\mathrm{K}$ & bND & ${ }^{b} N D$ \\
\hline $\mathrm{L}$ & ${ }^{b} N D$ & ${ }^{b} N D$ \\
\hline M & 0.035 & $3.9 \pm 0.3$ \\
\hline
\end{tabular}

a maximum concentration allowed by ANVISA it is $0.2 \%$. ${ }^{b} \mathrm{ND}$ : Not determined.

\section{Labels Analysis}

The results obtained in Table 2 show the labeling analysis of the 13 hair straightening samples, following the criteria established by the National Legislation - RDC 07/2015 which defines the mandatory labeling standards for cosmetic products.

Table 2. Labeling analysis of hair straightening samples.

\begin{tabular}{|c|c|c|c|c|c|c|c|c|c|c|c|c|c|}
\hline \multirow[b]{2}{*}{ Label criteria } & \multicolumn{13}{|c|}{ Samples } \\
\hline & $A$ & $B$ & $\mathrm{C}$ & $D$ & $E$ & $\mathrm{~F}$ & $G$ & $\mathrm{H}$ & I & J & $\mathrm{K}$ & L & $\mathrm{M}$ \\
\hline Name & as & as & as & as & as & as & as & as & as & as & as & as & as \\
\hline Brand & as & as & as & as & as & as & as & as & as & as & ${ }^{a} \mathrm{~S}$ & as & as \\
\hline $\begin{array}{l}\text { Registration } \\
\text { number }\end{array}$ & as & as & as & as & as & as & as & as & as & as & as & as & as \\
\hline Lot & as & ${ }^{b} \mathrm{~N}$ & ${ }^{a} \mathrm{~S}$ & as & ${ }^{\mathrm{a} S}$ & as & as & as & as & ${ }^{b} \mathrm{~N}$ & as & as & as \\
\hline $\begin{array}{l}\text { Expiration } \\
\text { date }\end{array}$ & as & ${ }^{\mathrm{b}} \mathrm{N}$ & as & as & as & as & as & as & as & ${ }^{\mathrm{b}} \mathrm{N}$ & as & as & as \\
\hline Content & as & as & ${ }^{a} \mathrm{~S}$ & as & as & as & ${ }^{a} \mathrm{~S}$ & as & as & as & as & as & as \\
\hline $\begin{array}{c}\text { Country of } \\
\text { origin }\end{array}$ & as & as & as & as & as & as & ${ }^{a} \mathrm{~S}$ & as & as & as & ${ }^{a} \mathrm{~S}$ & as & as \\
\hline Manufacturer & as & as & as & as & as & as & as & as & as & as & as & as & as \\
\hline CNPJ & as & as & as & as & as & as & as & as & as & as & as & as & as \\
\hline Composition & cNF & ${ }^{c} N F$ & ${ }^{\mathrm{CNF}}$ & cNF & ${ }^{d} F$ & ${ }^{\mathrm{CNF}}$ & cNF & ${ }^{c} N F$ & ${ }^{c} \mathrm{NF}$ & cNF & ${ }^{c} \mathrm{NF}$ & ${ }^{\mathrm{CNF}}$ & dF \\
\hline $\begin{array}{l}\text { Specific } \\
\text { labeling }\end{array}$ & as & as & as & as & as & as & as & as & as & as & as & as & as \\
\hline $\begin{array}{c}\text { Professional } \\
\text { use }\end{array}$ & ${ }^{\mathrm{b}} \mathrm{N}$ & ${ }^{a} \mathrm{~S}$ & ${ }^{\mathrm{b}} \mathrm{N}$ & ${ }^{\mathrm{b}} \mathrm{N}$ & ${ }^{\mathrm{a} S}$ & as & ${ }^{b} \mathrm{~N}$ & ${ }^{\mathrm{b}} \mathrm{N}$ & ${ }^{b} \mathrm{~N}$ & ${ }^{\mathrm{b}} \mathrm{N}$ & ${ }^{b} \mathrm{~N}$ & ${ }^{\mathrm{b}} \mathrm{N}$ & ${ }^{\mathrm{b}} \mathrm{N}$ \\
\hline How to use & as & as & as & as & as & as & as & as & as & as & as & as & as \\
\hline $\begin{array}{l}\text { Usage } \\
\text { restrictions }\end{array}$ & ${ }^{\mathrm{b}} \mathrm{N}$ & ${ }^{\mathrm{b}} \mathrm{N}$ & ${ }^{\mathrm{b}} \mathrm{N}$ & ${ }^{\mathrm{b}} \mathrm{N}$ & ${ }^{\mathrm{b}} \mathrm{N}$ & ${ }^{\mathrm{b}} \mathrm{N}$ & ${ }^{b} \mathrm{~N}$ & ${ }^{\mathrm{b}} \mathrm{N}$ & ${ }^{b} \mathrm{~N}$ & ${ }^{\mathrm{b}} \mathrm{N}$ & ${ }^{\mathrm{b}} \mathrm{N}$ & ${ }^{\mathrm{b}} \mathrm{N}$ & ${ }^{\mathrm{b}} \mathrm{N}$ \\
\hline $\begin{array}{l}\text { Warning } \\
\text { phrases }\end{array}$ & as & ${ }^{\mathrm{a} S}$ & as & as & ${ }^{\mathrm{b}} \mathrm{N}$ & ${ }^{\mathrm{a} S}$ & as & as & as & ${ }^{a} \mathrm{~S}$ & as & ${ }^{\mathrm{a} S}$ & ${ }^{\mathrm{b}} \mathrm{N}$ \\
\hline
\end{tabular}

aS- contains on the label; ${ }^{b} \mathrm{~N}$ - does not contain on the label; ${ }^{\mathrm{N} F}$ - does not indicate the presence of formaldehyde on the label; ${ }^{d} \mathrm{~F}$ - indicates the presence of formaldehyde on the label.

In the analysis of the labels, all samples under study showed irregularities, in addition to not reporting restrictions on the use of products. Only samples $E$ and $M$ indicated the presence of formaldehyde in their composition on their labeling. Samples A, C, D, G, 
$H, I, J, L$ and $M$ did not indicate that the product is for professional use. Samples B and J did not indicate batch and expiration date. Sample $L$ did not report that it is necessary to keep the product out of the reach of children and samples $E$ and $M$ did not indicate care with the use on irritated or injured scalp. Thus, the aforementioned samples of hair straighteners do not follow the criteria established by the National Legislation - RDC 07/2015.

\section{DISCUSSION}

According to RDC No. 15/2013, the use of formaldehyde in hair straightening products is allowed only as a preservative in a maximum concentration of $0.2 \%$. Thus, with the exception of sample $A$ which presented $0.1 \%$ formaldehyde, other analyzed samples, B, C, D, E, G, H, I, J and M, presented a higher than permitted concentration of formaldehyde, varying from $3.5 \%$ to $14.5 \%$. Thus, it is noteworthy that the concentration of formaldehyde for many samples is above the limit recommended by the National Health Surveillance Agency (ANVISA), which is $0.2 \%$, and exposes the users to adverse effects for both the professional and its client. Although sample A having a formaldehyde concentration below to the limit allowed by Anvisa (0.1\%), it should be taken into account that the standard deviation (0.2) can cause a variation in the result for a lower concentration as well as for a higher concentration (in this case, being also above the allowed limit).

Other authors also found high levels of formaldehyde in their analyzes using the spectrophotometric method, such as the one used in this study, which can be mentioned: Barroncas (2016) and Crippa et al. (2015) who find similar levels of formaldehyde to this study, both analyzed ten samples of hair straighteners and obtained formaldehyde percentages between $0.6 \%$ to $24 \%$ and between $0.04 \%$ to $18.50 \%$ respectively (Barroncas, 2016; Crippa et al., 2015). Moro et al. (2015) obtained $61.5 \%$ of samples with a formaldehyde percentage above $0.2 \%$, containing, in most of them, an amount ten times greater than allowed by the legislation (Moro et al., 2015). The authors considered that the high percentages of formaldehyde in hair straighteners is a public health problem and can carry several health risks. Thus, a stricter inspection of these products becomes extremely necessary.

Finally, it is worth mentioning that this improper use can cause serious damage to health, both for the user and for the professionals who apply the product, being this risk proportional to the concentration and frequency of use since formaldehyde generates an irritating action mainly on the upper respiratory tract and mucous membrane of the eyes, in addition to being classified as a carcinogen, since the literature shows that prolonged exposure to formaldehyde can cause nasopharyngeal carcinoma (Draelos, 1999; Instituto Nacional de Câncer, 2018).

In this context, the evaluation of the labeling parameters of products for progressive brush becomes essential, as can be seen in this research, since all samples analyzed, except sample $A$, failed in informe the presence of formaldehyde, containing concentration higher than permitted, in addition to irregularities in the labels, for example, some samples without expiration date, without batch, among others. Fact that can cause irreversible damage to the hair and scalp, in addition to damage to the human healthy, such as hypersensitivity reactions and cancer.

These results are in agreement with those verified by Abreu et al. (2015) who analyzed the labels of eight hair straightening samples using the criteria established by the National Legislation - RDC 07/2015 and also noted irregularities in the hair straightening labels (Abreu et al., 2015).

Sversut et al. (2017) analyzed ten samples of hair straighteners and also found irregularities in the expiration date and lot, as was also verified in this study. According to the authors, products beyond the expiration date contributes to the ocurrence of adverse reactions to the consumer, in addition to probably being ineffective in relation to their effect since, studies of component stability are carried out until that date recommended in the packaging as the expiration date (Sversut et al., 2017).

According to Rito et al. (2012) who evaluated one hundred and twenty samples of cosmetics, with nine samples of hair straighteners, the main flaws found in hair straighteners 
were in relation to not including the warning phrases and the lack of the date of manufacture. Because, according to the authors, the label should contain instructions for use in order to avoid misuse. Thus, the labeling of these products is, in most cases, incomplete and inconsistent, although there is specific legislation for this product category (Rito et al., 2012).

Finally, other studies that assess irregular concentrations of formaldehyde in hair straightening products should be encouraged, especially in different geographic regions, since they can serve as an alert to the health authorities.

\section{CONCLUSION}

In view of these results, it can be observed that even with the current legislation that limit the use of formaldehyde in hair straighteners, its irregular use still persists, and in a concentration above to the allowed. The irregular use of formaldehyde in hair straighteners is a public health problem and can carry several health risks. For this reason, it is essential to increase efforts related to the surveillance of cosmetic products to guarantee their quality, especially for hair straighteners. In addition, the need to raise the awareness of users of these products is emphasized, so that they understand, in more detail, what are the risks involved in irregular use. For this, actions such as, the distribution of booklets and guidance pamphlets for both professionals and customers who will use these products should happen.

\section{ACKNOWLEDGMENTS}

The authors would like to thank the support for the infrastructure provided by the University of Araraquara - UNIARA and for the financial support of the National Council for Technological and Scientific Development of Brazil - CNPq Grant n 137253/2015.

\section{REFERENCES}

Abraham LS, Moreira AM, Moura LH, Gavazzoni MFR, Addor MFS. Tratamentos estéticos e cuidados dos cabelos: uma visão médica (parte 1). Surg Cosmet Dermatol. 2009a;1(3):130-6.

Abraham LS, Moreira AM, Moura LH, Dias MFRG, Addor FAS. Hair care: a medical overview (part 2). Surg Cosmet Dermatol. 2009b;1(4):178-85.

Abreu VM, Azevedo MGB, Falcão JSA. Cosmetovigilância em alisantes capilares: determinação do teor de formaldeído por espectrofotometria e avaliação do rótulo. Rev Cienc Farm Basica Apl. 2015;36(1):51-8.

Agência Nacional de Vigilância Sanitária - ANVISA. Guia de controle de qualidade de produtos cosméticos. uma abordagem sobre os ensaios físicos e químicos [Internet]. Brasília: Editora ANVISA; 2007 [cited 2018 Dec 10]. Available from: https://www.crq4.org.br/downloads/guia_cosmetico.pdf

Agência Nacional de Vigilância Sanitária - ANVISA. Formol: pesquisa revela uso irregular [Internet]. Brasília: ANVISA; 2018 [cited 2018 Nov 25]. Available from: http://portal.anvisa.gov.br/noticias//asset_publisher/FXrpx9qY7FbU/content/pesquisa-uso-irregular-de-formol-em-saloes-debeleza/219201

AIShehri MM, AIMeshal MA. Pre-column derivatization HPLC method for rapid and sensitive determination of free and total formaldehyde in hair straightening products. Arab J Chem. 2020;13(1):2096-100. http://dx.doi.org/10.1016/j.arabjc.2018.03.008.

Alves CA, Aciole SDG. Formaldeído em escolas: uma revisão. Quim Nova. 2012;35(10):2025-39. http://dx.doi.org/10.1590/S0100-40422012001000024.

Atkins $\mathrm{P}$, Jones L. Princípios de química: questionando a vida moderna e o meio ambiente. 5. ed. Porto Alegre: Bookman; 2011.

Barroncas JS. Análise de formaldeído em amostras de produtos capilares no município de Manaus, AM [relatório científico]. Amanozas: UFAM; 2016.

Brasil. Agência Nacional de Vigilância Sanitária. RDC n 36, de 17 de junho de 2009. Dispõe sobre a proibida a exposição, a venda e a entrega ao consumo de formol ou de formaldeído (solução a 
37\%) em drogaria, farmácia, supermercado, armazém e empório, loja de conveniência e drugstore. Diário Oficial da União; Brasília; 18 jun 2009. 114:47. Seção 1.

Brasil. Agência Nacional de Vigilância Sanitária. RDC n 15, de 26 de março de 2013. Aprova o Regulamento Técnico “LISTA DE SUBSTÂNCIAS DE USO COSMÉTICO: ACETATO DE CHUMBO, PIROGALOL, FORMALDEÍDO E PARAFORMALDEÍDO" e dá outras providências. Diário Oficial da União; Brasília; 27 mar 2013; 59:55. Seção 1.

Brasil. Agência Nacional de Vigilância Sanitária. RDC $n^{\circ}$ 07, de 10 de fevereiro de 2015. Dispõe sobre os requisitos técnicos para a regularização de produtos de higiene pessoal, cosméticos e perfumes e dá outras providências. Diário Oficial da União; Brasília; 11 fev 2015; 29:39. Seção 1.

Crippa VO, Teixeira LRF, Rebello LC. Análise quali-quantitativa de formaldeído em amostras de produtos destinados ao alisamento capilar utilizados em salões de beleza no município de Linhares, Es - Brasil. Infarma - Ciências Farm. 2015;27(1):22.

Dias MFRG, Pirmez R, Dutra H, Tosti A. Hair straightening and hair dyes: facts and controversies. In: Tosti A, Asz-Sigall D, Pirmez R. Hair and scalp treatments. Switzerland: Springer; 2020. p. 285-90. http://dx.doi.org/10.1007/978-3-030-21555-2_19.

Diseró B. Uso exagerado de formol em salões de beleza causa impactos à saúde [Internet]. São Paulo: Jornal da USP; 2019 [cited 2018 Nov 25]. Available from: https://jornal.usp.br/atualidades/usoexagerado-de-formol-por-saloes-de-beleza-causa-impactos-a-saude/

Draelos ZD. Cosméticos em dermatologia. 2. ed. Rio de Janeiro: Revinter; 1999.

Franquilino E. Escovas progressivas: mecanismo de ação, opções ao formol e novidades do mercado. Cosmetics \& Toiletries. 2013;25(25):21-5.

G1. Formol é usado ilegalmente em salões de beleza para alisar os cabelos [Internet]. 2012 [cited 2018 Nov 25]. Available from: http://g1.globo.com/fantastico/noticia/2012/01/formol-e-usadoilegalmente-em-saloes-de-beleza-para-alisar-os-cabelos.html

Galli CL, Bettin F, Metra P, Fidente P, De Dominicis E, Marinovich M. Novel analytical method to measure formaldehyde release from heated hair straightening cosmetic products: impact on risk assessment. Regul Toxicol Pharmacol. 2015;72(3):562-8. http://dx.doi.org/10.1016/j.yrtph.2015.05.010. PMid:26003512.

Gasparini F, Weinert PL, Lima LS, Pezza L, Pezza HR. A simple and green analytical method for the determination of formaldehyde. J Braz Chem Soc. 2008;19(8):1531-7. http://dx.doi.org/10.1590/S0103-50532008000800012.

Instituto Nacional de Câncer - INCA. Formol ou formaldeído [Internet]. Brasília: INCA; 2018 [cited 2018 Dec 18]. Available from: http://www1.inca.gov.br/impressao.asp?op=cv\&id=795

International Agency for Research on Cancer - IARC. IARC Monographs on the Evaluation of Carcinogenic Risks to Humans [Internet]. Lyon: IARC; 2006 [cited 2018 Aug 3]. Available from: https://monographs.iarc.fr/wp- content/uploads/2018/06/mono88.pdf

Leite MGA, Garbossa WAC, Campos PMBGM. Hair straighteners: an approach based on science and consumer profile. Braz J Pharm Sci. 2018;54(3):1-8. http://dx.doi.org/10.1590/s217597902018000317339.

Martins GBC, Sucupira RR, Suarez PAZ. Papel indicador colorimétrico para detecção de formol em produtos lácteos e produtos de higiene pessoal. Quim Nova. 2017;40(8):946-51. http://dx.doi.org/10.21577/0100-4042.20170102.

Miralles P, Chisvert A, Alonso MJ, Hernandorena S, Salvador A. Determination of free formaldehyde in cosmetics containing formaldehyde-releasing preservatives by reversed-phase dispersive liquidliquid microextraction and liquid chromatography with post-column derivatization. J Chromatogr A. 2018;1543:34-9. http://dx.doi.org/10.1016/j.chroma.2018.02.031. PMid:29478830.

Monakhova YB, Kuballa T, Mildau G, Kratz E, Keck-Wilhelm A, Tschiersch C, Lachenmeier DW. Formaldehyde in hair straightening products: Rapid $1 \mathrm{H}$ NMR determination and risk assessment. Int J Cosmet Sci. 2013;35(2):201-6. http://dx.doi.org/10.1111/ics.12027. PMid:23216202.

Moro J, Claudino T de S, Deuschle RAN, Deuschle VCKN, Fritz FS, Hansen D, Bortolotto JW, Paim CS. Avaliação qualitativa e quantitativa de formaldeído em produtos cosméticos para alisamento capilar. Rev Cienc Farm Basica Apl. 2015;36(4):517-23. 
Rito PN, Presgrave RF, Alves EN, Huf G, Vilas Bôas MH. Avaliação dos aspectos do controle da qualidade de produtos cosméticos comercializados no Brasil analisados pelo Instituto Nacional de Controle de Qualidade em Saúde. Rev Inst Adolfo Lutz. 2012;71(3):557-65.

Russel JB. Química geral. 2. ed. São Paulo: Pearson Education do Brasil; 1994.

Silvestre ALP, Milani MI, Rossini EL, Pezza L, Pezza HR. A paper platform for colorimetric determination of aluminum hydrochloride in antiperspirant samples. Spectrochim Acta A Mol Biomol Spectrosc. 2018;204:432-5. http://dx.doi.org/10.1016/j.saa.2018.06.049. PMid:29966896.

Souza AMF, Santana DP, Lima ZN. Avaliação da qualidade de alisantes capilares : determinação da segurança quanto à análise de ingredientes ativos e contaminantes microbiológicos. Rev Bras Farm. 2012;93(3):331-6.

Stewart M, Bausman T, Kumagai K, Nicas M. Case study: formaldehyde exposure during simulated use of a hair straightening product. J Occup Environ Hyg. 2013;10(8):37-41. http://dx.doi.org/10.1080/15459624.2013.799978. PMid:23767851.

Sversut RA, Ferreira AD, Letícia E, Toledo M. Avaliação da qualidade de alisantes capilares contendo tioglicolato de amônio. Rev Colomb Cienc Quím Farm. 2017;46(3):303-18.

Ucko DA. Química para as ciências da saúde: uma introdução à química geral, orgânica e biológica. 2th ed. São Paulo: Manole; 1992.

Vitola JFS, Silva GR, Oliveira HR. Avaliação do teor de formaldeído em amostras de alisantes capilares utilizados em salões de beleza de Pedro Gomes, MS, Brasil. Infarma - Ciências Farm. 2019;31(1):28-33.

\section{Author contributions}

ALPS: conceptualization, analysis, methodology, data curation, writing; MF: conceptualization, analysis, methodology, data curation, writing; MGJAC: data curation, writing; BGCA: conceptualization, analysis, methodology, data curation, writing, supervision; TPF: conceptualization, data curation, writing, supervision. 